\title{
Soil Water Storage Temporal Stability With and Without Outliers
}

\author{
Alexsandro dos Santos Brito ${ }^{1}$, Paulo Leonel Libardi ${ }^{2}$, Jaedson Cláudio Anunciato Mota ${ }^{3}$ \\ \& Sergio Oliveira Moraes ${ }^{2}$ \\ ${ }^{1}$ Baiano Federal Institute of Education, Science and Technology (IFBAIANO), Guanambi, Bahia, Brazil \\ ${ }^{2}$ Department of Biossystens Engineering, "Luiz de Queiroz" College of Agriculture, Piracicaba, São Paulo, \\ Brazil \\ ${ }^{3}$ Department of Soil Sciences, Federal University of Ceará, Fortaleza, Ceará, Brazil \\ Correspondence: Alexsandro dos Santos Brito, Baiano Federal Institute of Education, Science and Technology \\ (IFBAIANO), Guanambi, Bahia, Brazil. E-mail: alexsandro.brito@ifbaiano.edu.br
}

Received: August 21,2019 Accepted: September 30,2020 Online Published: October 15, 2020
doi:10.5539/jas.v12n11p234
URL: https://doi.org/10.5539/jas.v12n11p234

This research is financed by CNPq financial resource (Process number 477215/2007-6).

\begin{abstract}
The knowledge on the temporal stability of spatial variability of soil water storage in the crops' root zone is of fundamental importance for soil and water management. The objective of this work was to characterize the temporal distribution of water storage in a Latossolo vermelho amarelo and identify field locations with spatial patterns of high, intermediate and low soil water storage, in 13 samplings every 14 days. The assessed period included periods of drying and water recharge of the soil, along which soil water content was determined at 60 sampling points arranged in a $5 \times 5 \mathrm{~m}$ grid covering an area of $1250 \mathrm{~m}^{2}(25 \times 50 \mathrm{~m})$. Soil water content was determined by means of a neutron probe, at soil depths of $0.2,0.4,0.6,0.8$ and $1.0 \mathrm{~m}$. Soil water storage was calculated by Simpson's rule and data were analyzed by the temporal persistence of the spatial pattern. Maximum values of soil water storage were obtained at the portion of the area with water flux concentration (sampling points 4, 28 and 57), with and without outliers, and low values of soil water storage were obtained at the highers levels of the site (sampling points 12, 18 and 19), with and without outliers. The sites representing the mean soil water storage were 32,51 and 11 , considering outliers, and 8,11 and 53, without considering outliers.
\end{abstract}

Keywords: temporal persistence, soil water content, neutron probe

\section{Introduction}

Mechanical practices carried out from soil tillage to the end of the crop cycle and irrigation management and adequacy are influenced by the behavior of water in the soil (Fietz et al., 1999). Since soil water storage results from a series of processes, especially infiltration, surface runoff, percolation and evapotranspiration (Hu et al., 2009), its monitoring along the development of a crop provides essential elements to the establishment or enhancement of agricultural management practices that aim to optimize yield (Brito et al., 2009), particularly for cultivation practices and mechanical practices, which may lead to degradation of soil physical quality and reduction in yield.

In this aspect, knowledge on the spatial variability of soil attributes is essential to applying the most appropriate management system to each plot of land (Corá et al., 2004; Vieira et al., 2007). On the other hand, as a criteria to choose sampling sites more representative of the behavior of dynamic attributes, such as soil water storage, one may assess the temporal stability of the spatial distribution of soil water storage (Rocha et al., 2005), according to Vachaud et al. (1985). In this work, Vachaud et al. (1985) presented two techniques to study the temporal variability of soil water storage, based on the temporal persistence of a spatial pattern, which is evaluated by the analysis of correlation of measurements on successive dates.

The first technique suggested is the Spearman's non-parametric test, generating a position correlation matrix, corresponding to the evaluation dates. This technique is an exploratory tool to characterize the level of temporal persistence of the variable under study. The second technique, the relative difference, allows to identify sites that 
maintain the magnitude of the average temporal value and those that diverge from the mean, either underestimating or overestimating it. Therefore, these techniques allow to reduce the sampling effort and the time of decision-making regarding the execution of management practices. Thus, identifying temporally stable sites of soil water storage has been one of the main applications of this technique (Gao et al., 2015).

Temporal persistence is usually related to some deterministic factor (attribute or process). Water storage at a certain site results from a set of hydrological processes that occur at different spatial scales (Kachanoski \& De Jong, 1988). Internal drainage and capillary rise are water flows that occur in the soil volume explored by the crops (Timm et al., 2002; Cruz et al., 2005, Brito et al., 2009, Salvador et al., 2012, Libardi et al., 2015), which are influenced by soil texture, structure and morphology.

Water storage results from soil texture and structure (Rocha et al., 2005; Suzuki et al., 2014), soil cover (Mota et al., 2010) and presence of small depressions on soil surface, which promote higher water retention (Salvador et al., 2012). Regarding texture, in a soil with uniform profile, such as Latossolos, clay and sand contents possibly do not influence water storage over time (Rocha et al., 2005). Nonetheless, textural variation in soils with more stratified profile may lead to a hydraulic behavior completely different from the spatial pattern, because it alters the processes of water entry and exit in the soil profile.

Management adequacy is also another concern that has been studied, especially regarding water availability and its relationship with the type of soil and regional climate. In this aspect, spatial variability is an important topic in the implementation of a specific management that optimizes the agricultural production system. The spatial variability of water content, in the $0-0.15 \mathrm{~m}$ layer, is higher in the direct seeding system than in the conventional cultivation system (Zanette et al., 2007). Plowing and harrowing operations promote greater uniformization of the soil, while in the direct seeding the action of biological processes is more predominant and random in space, leading to higher variability (Schaffrath et al., 2008), which has not caused damages.

Based on the hypothesis that, even in an area considered as homogeneous, the microrelief, for conditioning variation in soil physical attributes, directly influences water storage, this study aimed to characterize, using the relative difference technique, the temporal persistence of water storage in a Red Yellow Latosol, with and without outliers, and identify a set of sampling sites with spatial pattern of high, medium and low soil water storage, as a function of 13 samplings spaced by 14-day periods, in a 60-point regular grid.

\section{Methods}

\subsection{Characterization of the Experimental Area}

The study was conducted in an experimental area of the "Luiz de Queiroz" College of Agriculture, located in the municipality of Piracicaba, São Paulo state, Brazil. The geographic coordinates in the center of the area are $22^{\circ} 42^{\prime} 43^{\prime \prime} \mathrm{S}, 47^{\circ} 37^{\prime} 10^{\prime \prime} \mathrm{W}$, with mean altitude of $591 \mathrm{~m}$. The soil was classified as dystrophic Red Yellow Latosol (EMBRAPA, 2013).

To evaluate the influence of the relief, which is considered as flat undulating, in the study on water storage, a contour map was made using a sub-meter GPS, model Pro XL (Trimble), through the differential method.

In this experimental area, 60 access tubes of a neutron probe (CPN 503 Hydroprobe $^{\mathrm{TM}}$, with $50 \mathrm{mCi}$ Americium-Beryllium source) were installed, arranged in a regular grid $(6 \times 10$ points $)$, spaced by $5.0 \mathrm{~m}$. The tubes were $2.1 \mathrm{~m}$ long, and $0.2 \mathrm{~m}$ of their length was left above the soil surface.

\subsection{Soil Physical-Hydraulic Characterization}

For physical characterization, disturbed soil samples were collected at $0.2,0.4,0.6,0.8$ and $1.0 \mathrm{~m}$ depths at the 60 sampling points of the regular grid at a distance of $1.30 \mathrm{~m}$ from the neutron probe access tube (installed in the center of each sampling point), totaling 300 samples. These samples were used in the granulometric analysis, which was carried out using the pipette method (Gee \& Or, 2002), using a dispersing solution composed by sodium hydroxide $\left(4 \mathrm{~g} \mathrm{~L}^{-1}\right)$ and sodium hexametaphosphate $\left(10 \mathrm{~g} \mathrm{~L}^{-1}\right)$, according to the methodology of IAC (Camargo et al., 1986), and an automatic pipettor.

Undisturbed soil samples were also collected at the first 60 sampling points, at depths of $0.2,0.4$ and $0.6 \mathrm{~m}$ (three replicates) and at $0.8 \mathrm{~m}$ (five replicates), totaling 840 samples. These samples were used to determine bulk density and pore-size distribution.

Soil bulk density was determined by the volumetric cylinder method, using an Uhland sampler and approximately $0.05-\mathrm{m}$-high, $0.047-\mathrm{m}$-diameter volumetric cylinders. However, heights and diameters of all cylinders were previously measured, in three replicates, using digital caliper, to calculate the mean volume. In the laboratory, the samples were prepared by removing the excess soil from the cylinder and fixing a silk screen 
to the bottom of the sample using a rubber band to avoid loss of material. The samples were placed in an oven $\left(105^{\circ} \mathrm{C}\right.$, for 48 hours) and weighed to determine soil dry weight and, consequently, bulk density.

Soil porosity at $0.8 \mathrm{~m}$ depth was obtained based on the pore-size distribution recommended by Koorevaar et al. (1999), classifying the pores into: macropores (pores with radius larger than $50 \mu \mathrm{m}$ ), mesopores (pores with radius between 15 and $50 \mu \mathrm{m}$ ) and micropores (pores with radius smaller than $15 \mu \mathrm{m}$ ). For this procedure, one undisturbed soil sample from each sampling point was previously prepared, by removing the excess soil from the volumetric cylinder and placing a blotting paper with the same diameter as the cylinder at its bottom end to avoid loss of material.

The soil samples were placed in Haines' funnels and were saturated with deionized water, by gradually increasing the water level, for 24 hours. For the other tensions, the water level was raised up to approximately half the volumetric cylinder height. Haines' funnel was used for the tensions from 1 to $10 \mathrm{kPa}$, with measurements taken every $1 \mathrm{kPa}$, totaling 10 measurement points.

\subsection{Neutron Probe Calibration and Water Storage}

To calibrate the neutron probe, a sampling was firstly performed using the count of the probe with 30 -s reading time at depths of $0.2,0.4,0.6,0.8$ and $1.0 \mathrm{~m}$, to select sites that showed different counts. This procedure was carried out using the R Statistical Program and the functions "points" and "pt.div=quint (which classifies values into five levels)" of the GeoR Package (Ribeiro Júnior \& Diggle, 2001). The decision on which site would be sampled was made based on the count measured with the neutron probe at $0.4 \mathrm{~m}$ depth and using the counts at the other depths as covariables, since the objective is to study water storage until $1.0 \mathrm{~m}$ deep. A map of counts of the 60 sites was created for eight dates, which were representative of the periods of drying and water recharge of the soil (Figure 1). 

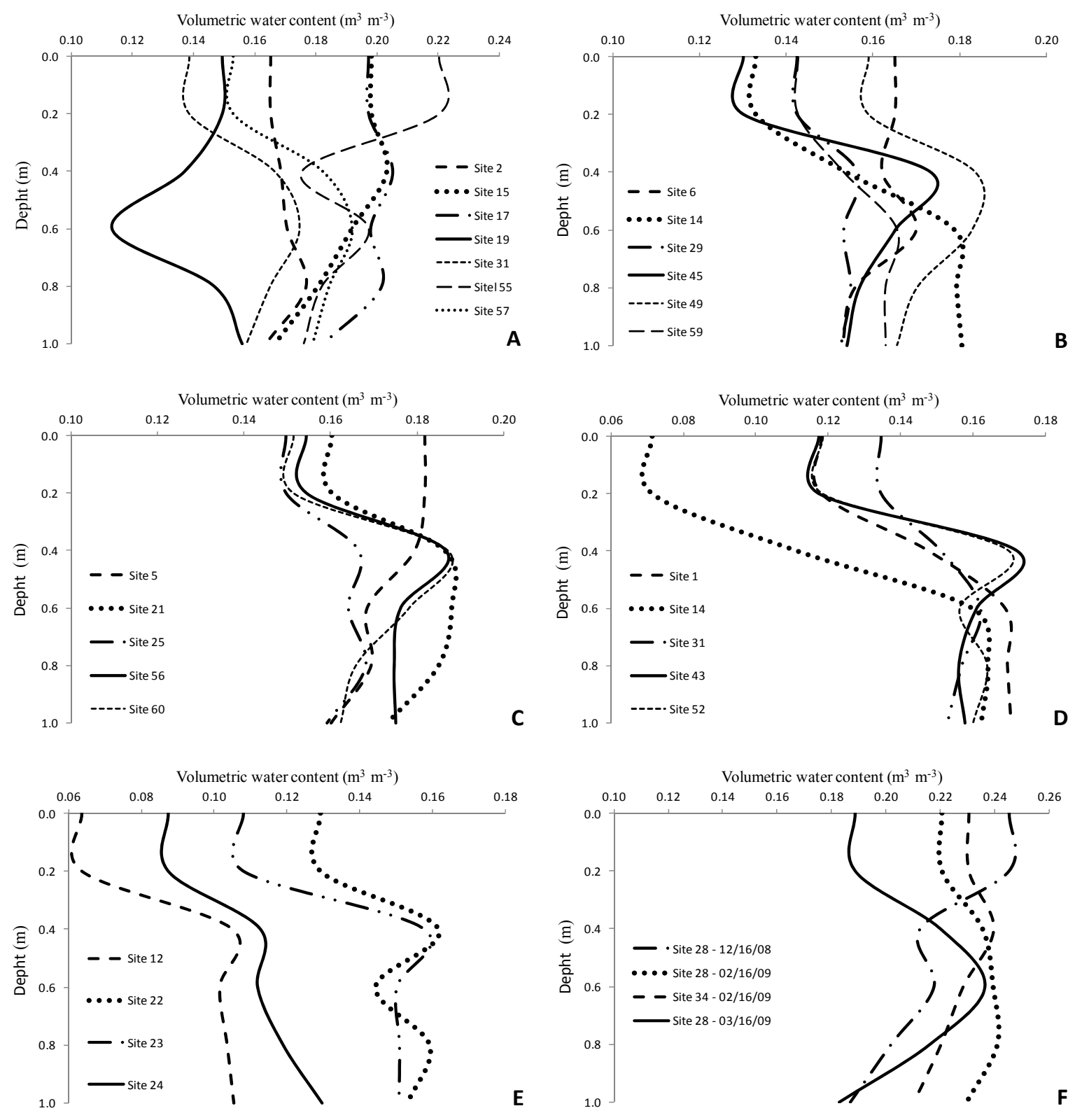

Figure 1. Volumetric water content profiles at the sites selected to calibrate the neutron probe on the following dates: 10/02/08 (A); 10/17/08 (B); 11/01/08 (C); 11/16/08 (D); 12/01/08 (E); 12/16/08, 02/16/09 and $03 / 16 / 09$ (F)

The counts made at depths of $0.2,0.4,0.6,0.8$ and $1.0 \mathrm{~m}$ (in three replicates) at the selected sites and at the standard position were used to calculate the mean relative counts- $\mathrm{RCm}$ (ratio between the mean count in the soil profile and the count at the standard position). Thus, the neutron probe calibration equation was obtained by the linear regression between water storage, calculated for the 1.0-m-deep soil profile, and the mean relative count (Figure 2). 


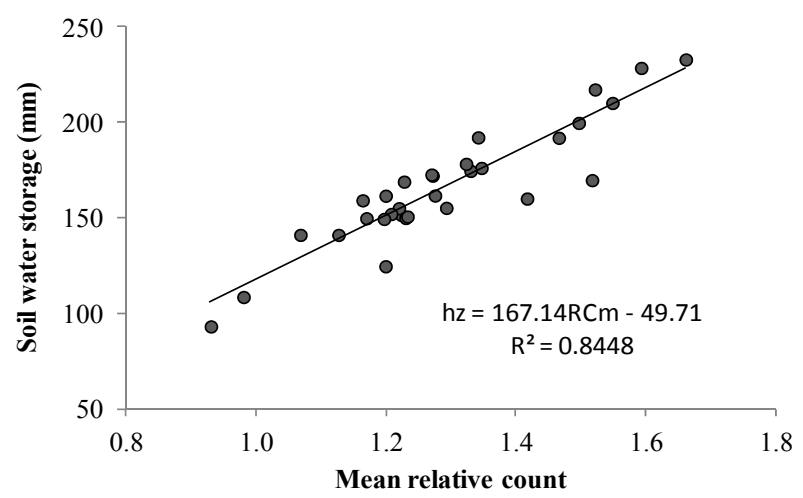

Figure 2. Neutron probe calibration curve constructed by the linear regression between soil water storage (mm) and mean relative count $(\mathrm{RCm})$

\subsection{Temporal and Geostatistical Analysis of Water Storage}

The parametric analysis technique (Vachaud et al., 1985) consists in the relative difference defined by the following equation:

$$
\hat{\delta}_{i j}=\frac{\omega_{i j}-\bar{\omega}_{j}}{\bar{\omega}_{j}}
$$

where, $\omega_{i j}$ is the water storage calculated at each sampling site, $i$, at the different monitoring times, $j$, and $\bar{\omega}_{j}$ is the average water storage of all sites, at each monitoring time $j$ :

$$
\bar{\omega}_{j}=\frac{1}{n} \sum_{i=1}^{n} \omega_{i j}
$$

Therefore, the time series (13 samplings performed every 14 days) has the intertemporal relative difference and the standard deviation of each sampling site:

$$
\begin{gathered}
\bar{\delta}_{i}=\frac{1}{m} \sum_{j=1}^{m} \delta_{i j} \\
\hat{\sigma}\left(\delta_{i}\right)=\sqrt{\frac{1}{m} \sum_{j=1}^{m}\left(\delta_{i j}-\bar{\delta}_{i}\right)^{2}}
\end{gathered}
$$

With these measurements, the site with $\bar{\delta}_{i} \cong 0$ and lowest $\sigma\left(\delta_{i}\right)$ is considered as the one that best represents the arithmetic mean of soil water storage. In addition, it was possible to select sites that underestimate and overestimate the studied variable. However, since it is a mean calculated as a function of the monitoring dates, an exploratory analysis was carried out in the values of the relative difference of the sampling sites as a function of time, to verify the existence of outliers. Such analysis was performed in the R statistical environment (R Development Core Team, 2018), using box plots, and outliers were values with 1.5 times the interquartile range $\left(\mathrm{Q}_{1}\right.$ and $\left.\mathrm{Q}_{3}\right)$.

To assist in the interpretation of the results, geostatistical analysis was carried out and prediction maps of the mean relative differences with and without the outliers were created, indicated by the exploratory analysis. These procedures were performed using the statistical program $\mathrm{R}$ and the GeoR and Mass packages.

Factors influencing the spatial distribution of the intertemporal relative difference of soil water storage were verified by principal component analysis (PCA), using the statistical program R and the Vegan package.

\section{Results and Discussion}

The relief in the experimental area is considered as flat undulating, with presence of higher portions (Figure 3) and a difference of $0.76 \mathrm{~m}$ between the highest and lowest elevations. The contour map is represented by contour lines relative to the highest elevation, and the sampling points indicated by yellow, red and blue arrows represent maximum, minimum and mean intertemporal water storages, respectively. 


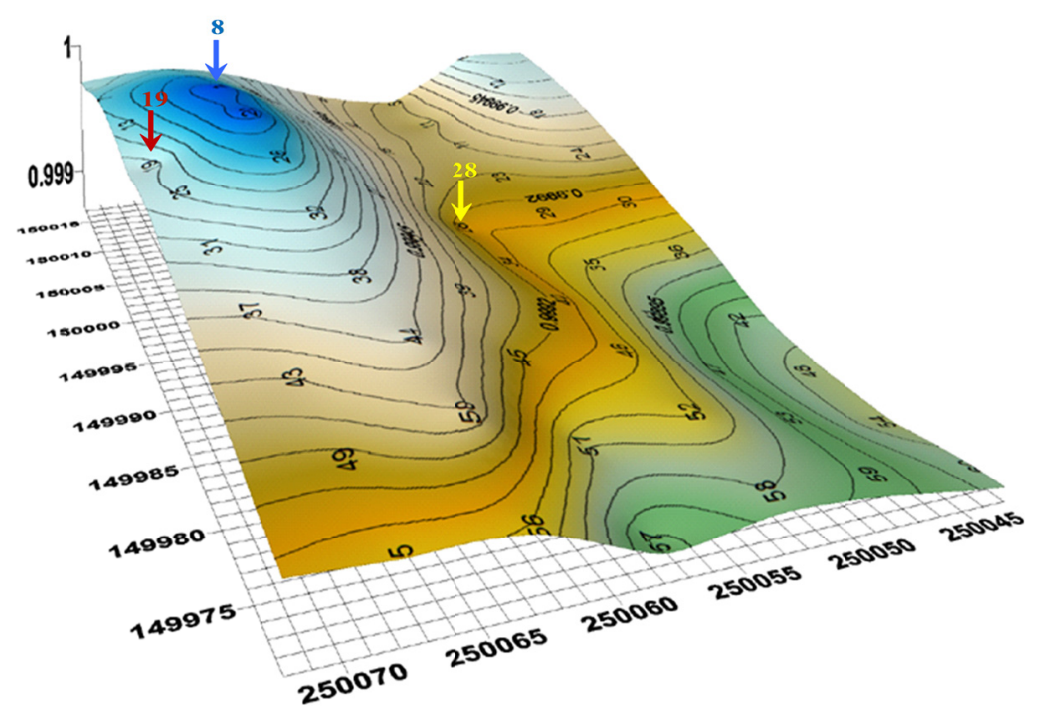

Figure 3. Contour map of the experimental area constructed with contour lines relative to the highest elevation, with the distribution of the sampling sites

The contour map with the results of granulometric analysis (Figure 4) clearly demonstrate that the sampling sites located at the highest portions of the terrain systematically show higher sand contents at 0.2 and $0.4 \mathrm{~m}$ depths, while those located at the lowest portions show higher clay contents, despite the small difference of elevation. For the 0.6 and $0.8 \mathrm{~m}$ depths, the granulometric fractions are very uniform, because of the homogeneity of the factors and processes of soil formation.
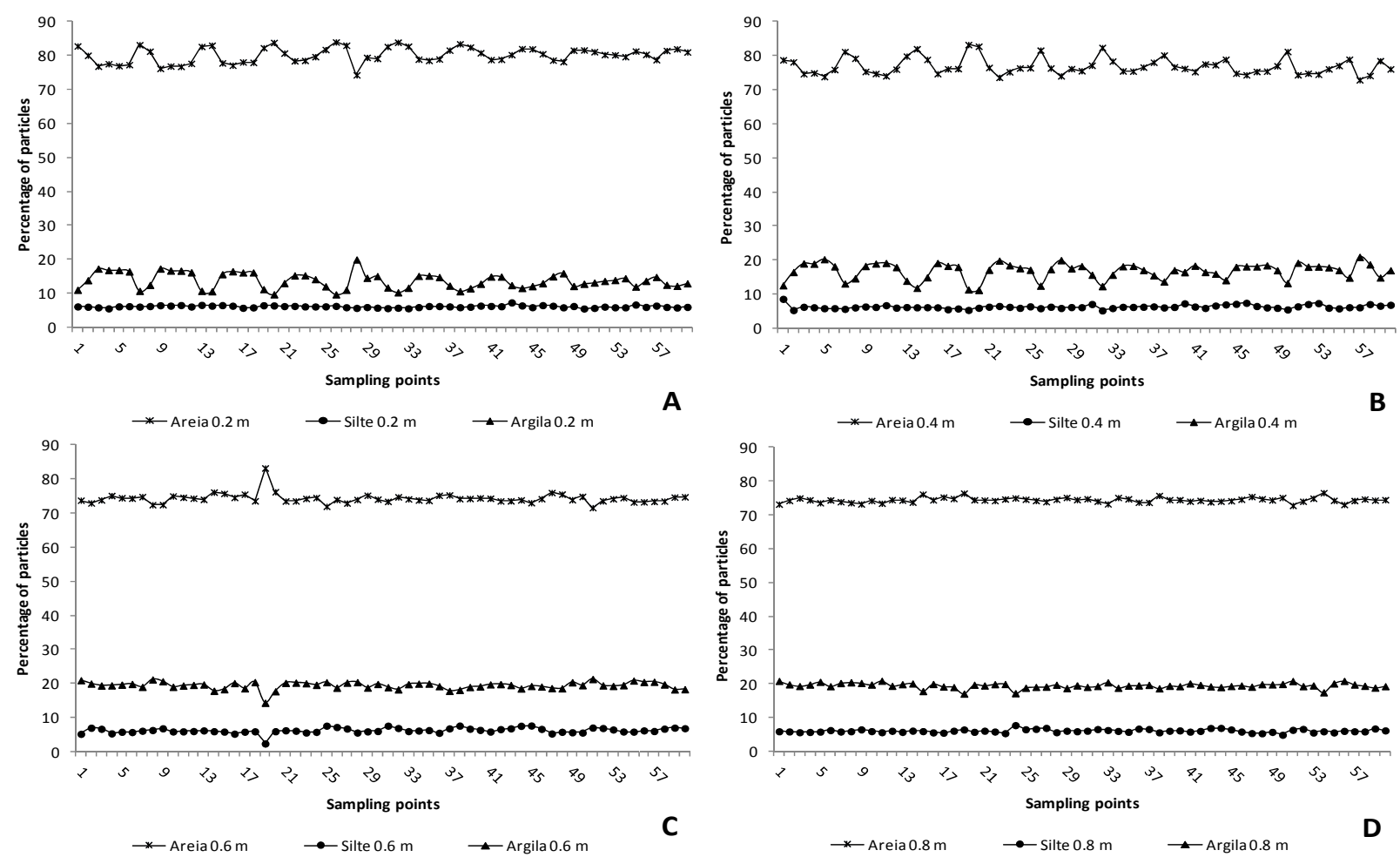

Figure 4. Percentages of sand, silt and clay at depths of $0.2 \mathrm{~m}(\mathrm{~A}), 0.4 \mathrm{~m}(\mathrm{~B}), 0.6 \mathrm{~m}(\mathrm{C})$ and $0.8 \mathrm{~m}(\mathrm{D})$ at the 60 sampling sites

For soil bulk density, since the area had been under fallow, without crops and with spontaneous vegetation for four years, and since no tillage practice was carried out, just a few passes with the mower for cleaning, the 
surface layer $(0-0.3 \mathrm{~m})$ showed high bulk density, evidencing a process of compaction (Table 1), because in sandy soils, as in the surface layer of this soil, bulk density may vary from 1.250 to $1.750 \mathrm{Mg} \mathrm{m}^{-3}$ (Brady and Weil 2002).

Pore-size distribution at the sampling point 28 was the most different, and the proportion of micropores was much higher compared with the other sites, in detriment of mesopores (Table 1). This is related to the higher clay content in the soil profile, besides the elevation and position in the experimental area, because it is one of the lowest sites and is located close to higher portions, which leads to greater accumulation of water.

Table 1. Soil bulk density as a function of depth (m) and soil porosity (\%) at $0.8 \mathrm{~m}$ depth

\begin{tabular}{|c|c|c|c|c|c|c|c|c|}
\hline & \multicolumn{4}{|c|}{ Bulk density $\left(\mathrm{Mg} \mathrm{m}^{-3}\right)$} & \multicolumn{4}{|c|}{ Soil porosity $(0.8 \mathrm{~m})$} \\
\hline & $0.2 \mathrm{~m}$ & $0.4 \mathrm{~m}$ & $0.6 \mathrm{~m}$ & $0.8 \mathrm{~m}$ & Macro & Meso & Micro & Total \\
\hline Mean* & 1.674 & 1.610 & 1510.8 & 1509.0 & 23.9 & 28.6 & 47.5 & 43.77 \\
\hline $\mathrm{SD}^{* *}$ & 0.046 & 0.074 & 0.050 & 0.030 & 2.9 & 5.1 & 4.1 & 1.5 \\
\hline Maximum & 1.770 & 1.799 & 1.619 & 1.598 & 32.4 & 37.4 & 59.4 & 47.8 \\
\hline Minimum & 1.568 & 1.400 & 1.371 & 1.444 & 16.0 & 16.6 & 38.4 & 39.7 \\
\hline
\end{tabular}

Note. * Means originated from the 60 sampling sites; ** Standard deviation.

Exploratory analysis, performed using box plots (Libardi et al., 1996), revealed the existence of outliers (Figure $5 \mathrm{~A})$ at 22 sites (circles indicate outliers) and on different dates. The highest number was detected between the days 5 and 19 of January, corresponding to the transition between the periods of drying and water recharge of the soil, as can be observed by the distributions of maximum, mean and minimum storages along the entire monitoring period (Figure $5 \mathrm{~B}$ ). Maximum and minimum storages were represented by the same sites (28 and 19, respectively), before and after removing the outliers.

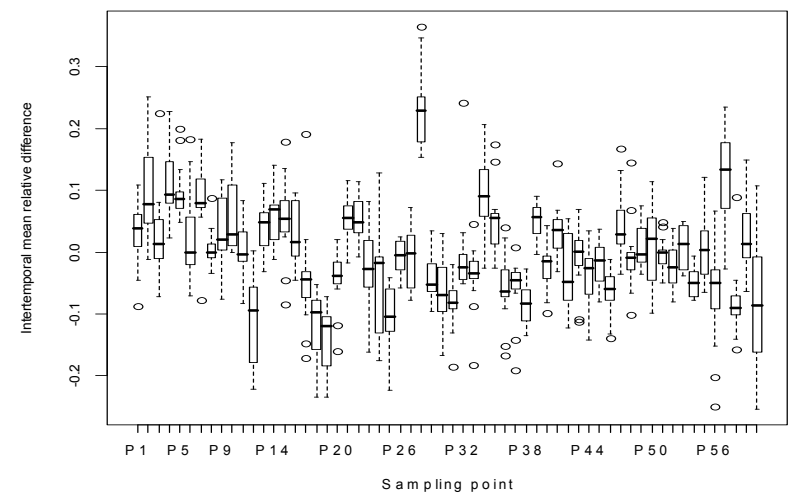

A

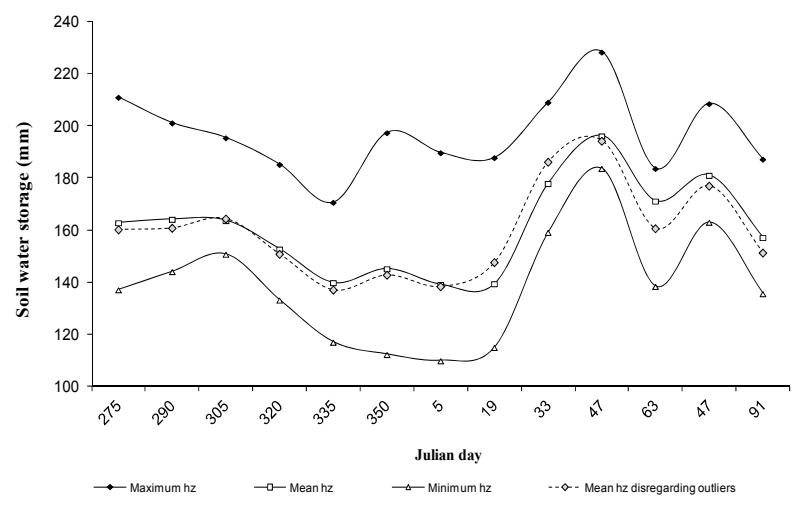

B

Figure 5. Box plot of the relative differences for the 60 sampling sites (A), in which circles represent outliers, and maximum, mean and minimum storages $(\mathrm{B})$, in which the dashed line represents the mean water storage without removing the outliers

It is important to point out that extreme values in the ranking of the intertemporal relative difference are affected by the existence of outliers with much lower intensity in comparison to the mean values. Such influence is represented by the dashed line in Figure 5B, which represents the mean water storage of the area, without removing the outliers. The sampling site representing the mean water storage changed from site 51 to site 8 as the outliers were removed (Figures 6A and 6B). This demonstrates the importance of the exploratory analysis and removal of possible outliers, because the mean water status in the soil is often the main interest.

Nevertheless, the point 53 appears among the three most representative sites of intertemporal mean water storage. Another study conducted in the same area, but in a bean/black oat succession, found that the most adequate site to determine mean water storage was the site 52 (Salvador et al., 2012), an intermediate point between 51 and 53 , 
which were found among the three most representative of mean water storage, with and without outliers, respectively.

The temporal stability technique applied to soil water storage, using a regular grid of sampling sites, and in a period of oscillation between processes of soil drying and wetting, proved to be able to identify the most appropriate sites for monitoring, reducing the sampling effort in future assessments of water status in this soil. Maximum water storage in the studied period was represented by the sites 4, 28 and 57 (177, 197 and $179 \mathrm{~mm}$, respectively), whereas mean water storage was represented by the sites 8,11 and 53 (161, 160 and $161 \mathrm{~mm}$, respectively) and minimum water storage by the sites 12,18 and 19 (143, 140 and $138 \mathrm{~mm}$, respectively) according to Figure $6 \mathrm{~B}$, which shows the ranking of the intertemporal relative difference of soil water storage for the entire grid of sampling sites.

Terrain morphology and higher and lower contents of clay and sand, respectively, at the sampling sites were deterministic factors, as highlighted by Kachanoski et al. (1988), allowing for a clearer interpretation of the temporal stability. The sampling site 28 , located at one of the lowest elevations and close to higher portions of the area, for instance, showed mean clay content of $199 \mathrm{~g} \mathrm{~kg}^{-1}$ in the soil profile, whereas the sites 8 and 19 , located at intermediate and high elevations, respectively, showed 177 and $145 \mathrm{~g} \mathrm{~kg}^{-1}$. Significant correlation of water storage with soil particle composition and organic matter has been found (Hu et al., 2009). The relief can also cause lateral water runoff to the lowest sampling sites on the terrain, especially in intense rainfall events or when the soil has high water storage and, consequently, lower water infiltration rate.
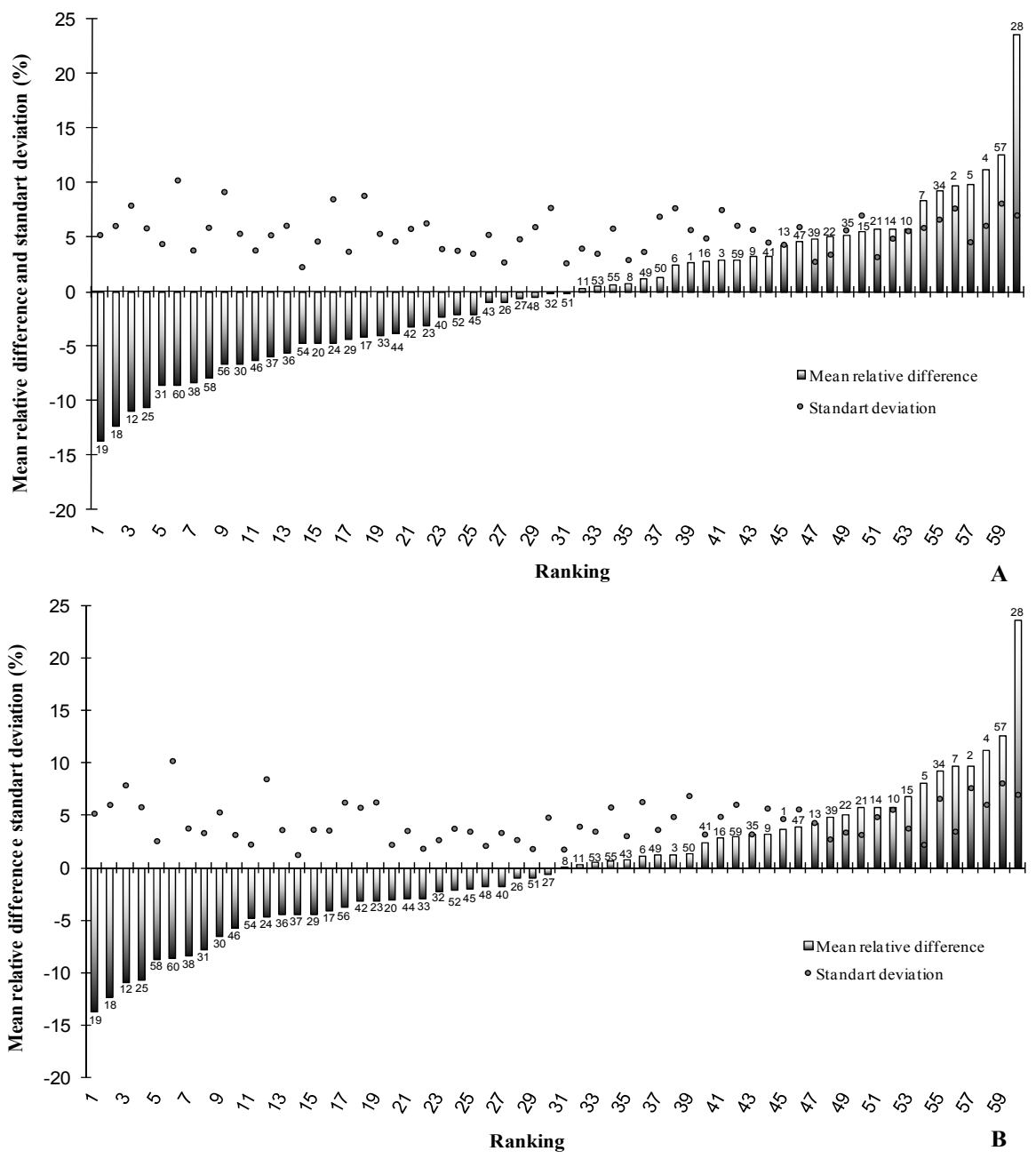

Figure 6. Intertemporal mean relative difference of soil water storage $(\mathrm{mm})$ and standard deviation ranked in ascending order for the data with (A) and without (B) outliers, with the distribution of sampling sites close to the bars 
With the interference of these small-scale factors, the water storage found in the sampling site 28 during the studied period was on average 22 and $42 \%$ higher than those of the sites 8 and 19, respectively. These are considerable differences and can cause variations in the productive aspects of the crops. The contribution from soil texture and structural properties (Melo Filho \& Libardi, 2005), as well as declivity and particularly the surface water runoff from higher sites (Brocca et al., 2009), act as preponderant factors in maintaining the temporal stability of sites with high values of soil water content and storage.

The attributes that most influence the spatial distribution of the intertemporal mean relative difference were soil bulk density at 0.6 and $0.8 \mathrm{~m}$ depths and clay contents at $0.6,0.8$ and $1.0 \mathrm{~m}$ depths, with a positive correlation. Sand contents at $0.6,0.8$ and $1.0 \mathrm{~m}$ depths have a negative correlation (Figure 7). It was observed that, since the granulometric fractions are complementary, clay percentages were found in quadrants 2 and 3, whereas sand percentages were found in quadrants 1 and 4 . Again, there was a correspondence between sand and clay contents at sampling sites located at higher and lower elevations, respectively.
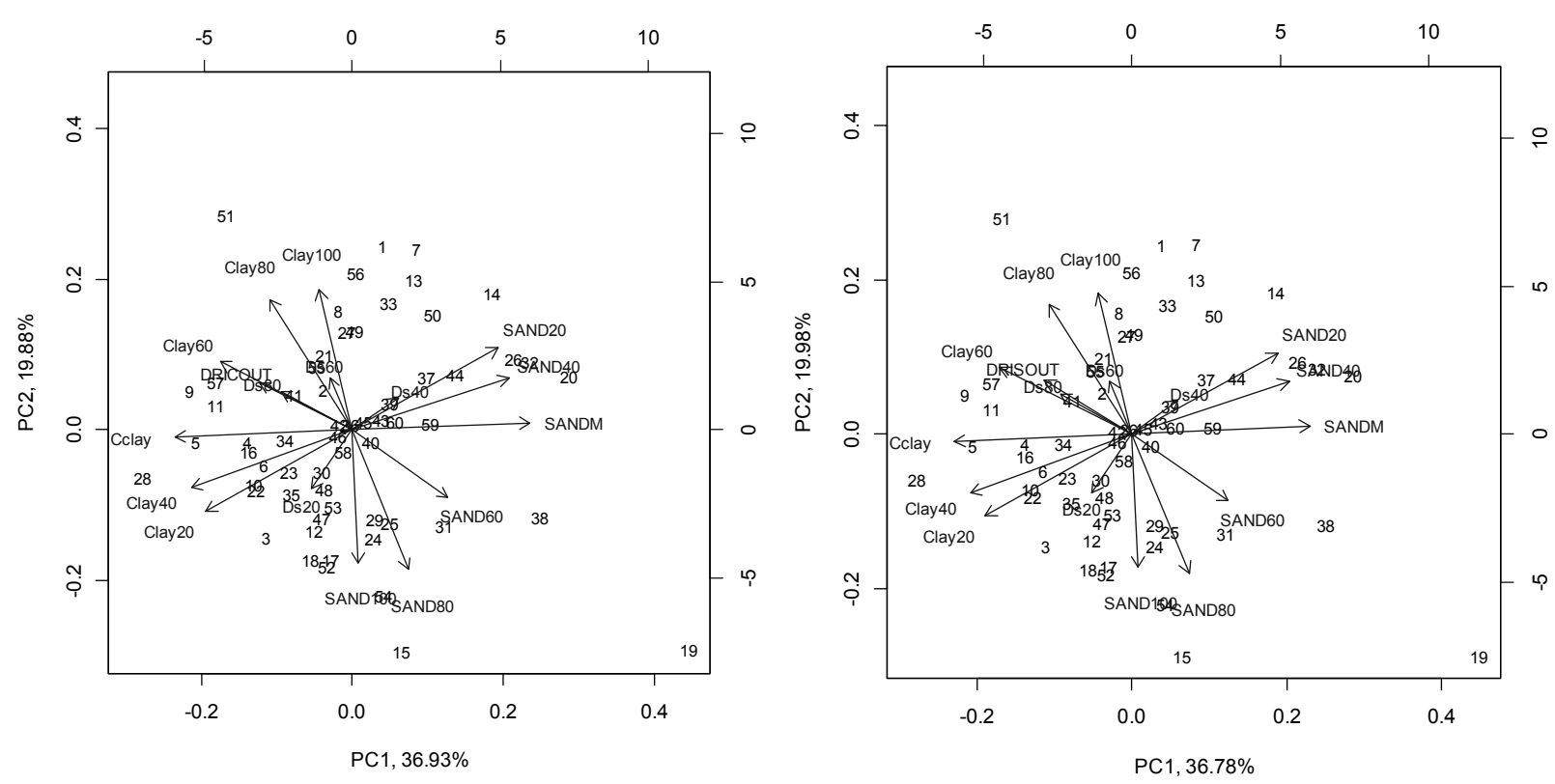

Figure 7. Dispersion of soil attributes and intertemporal relative difference of soil water storage (DRISOUT and DRICOUT - without and with outliers, respectively), where Clay20, Clay40, Clay06, Clay80, Clay100, SAND20, SAND40, SAND60, SAND80 and SAND100 are the percentages of clay and sand at depths of 0.2, $0.4,0.6,0.8$ and $1.0 \mathrm{~m}$, respectively; Cclay is the clay content in the soil profile $(0-1.0 \mathrm{~m})$; SandM is the mean sand percentage in the soil profile (0-1.0 m); Ds20, Ds40, Ds60 and Ds80 are soil bulk density values $\left(\mathrm{kg} \mathrm{m}^{-3}\right)$ at depths of $0.2,0.4,0.6$ and $0.8 \mathrm{~m}$, respectively

The clear relationship between water storages calculated at the site 28 along the evaluation period and the clay content in the soil profile was not that evident for the other sampling sites, leading to a weak correlation between these variables in the experimental area. Because of this behavior, the exploratory analysis of the data, for the PCA (Figure 7) and geostatistical analysis, prediction maps (Figure 8), indicated the site 28 as an outlier, and it was removed from both analyses.

In the prediction maps, with and without outliers (Figures $8 \mathrm{~A}$ and $8 \mathrm{~B}$, respectively), removing the outliers of the intertemporal mean relative difference caused slight homogenization of the spatialization. Nonetheless, it is possible to observe that the sampling point 51, considered as the best representation of mean water storage, disregarding the outliers, is found in a portion of the area that best represents this behavior, whereas the point 28 is isolated in a portion that represents more the high values of water storage in the studied area. 

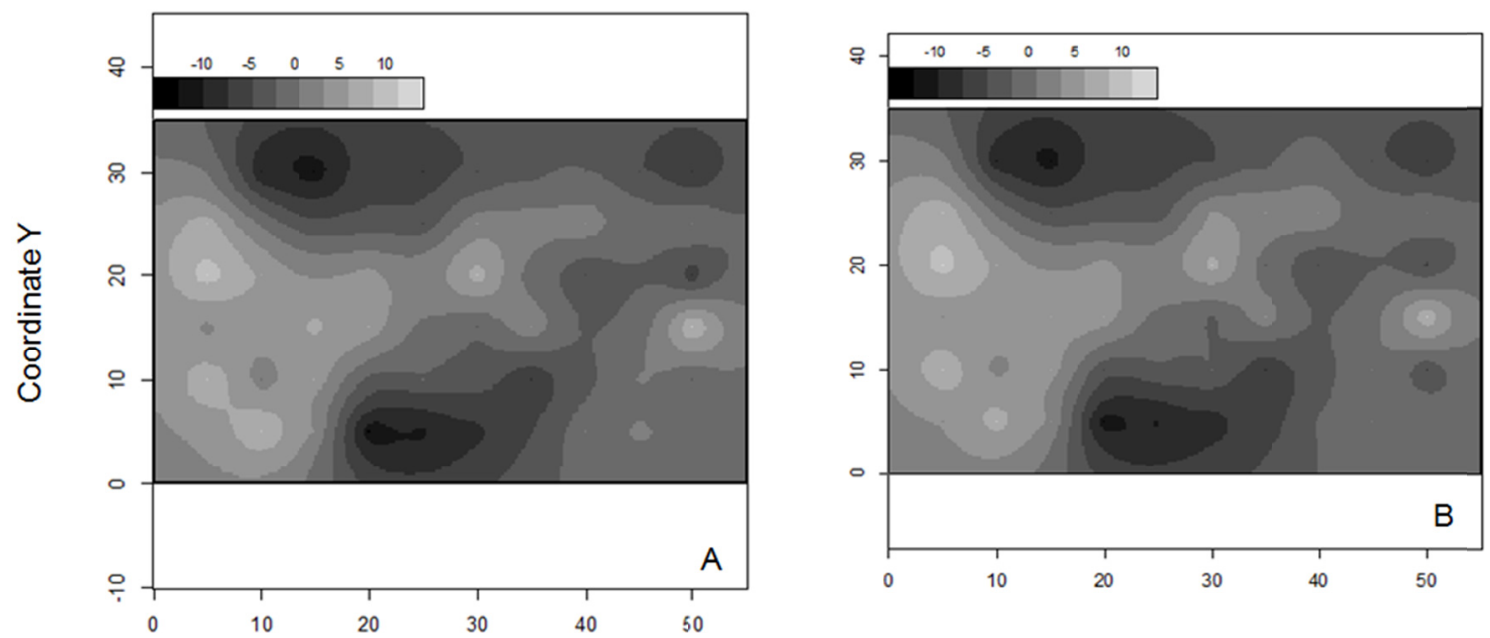

\section{Coordinate $X$}

Figure 8. Kriging maps of the relative differences of soil water storage with (A) and without (B) outliers found in the intertemporal series

\section{Conclusions}

Removal of outliers influenced only the determination of the intertemporal mean water storage.

The temporal stability of soil water storage, analyzed together with the deterministic factors (clay and sand contents, bulk density and relief), allowed to identify sites that represent mean, minimum and maximum water storages over time, with greater reliability.

\section{References}

Brady, N., \& Weil, R. R. (2002). The nature and properties of soils (13th ed.). New Jersey: Pearson-Prentice Hall.

Brito, A. S., Libardi, P. L., \& Ghiberto, P. J. (2009). Water Balance Components in Soils Cropped to Sugarcane, with and without Nitrogen Fertilization. Revista Brasileira de Ciência do Solo, 33, 295-303. https://doi.org/ 10.1590/S0100-06832009000200007

Brocca, L., Melone, F., Moramarco, T., \& Morbidelli, R. (2009). Soil moisture temporal stability over experimental areas in Central Italy. Geoderma, 148, 364-374. https://doi.org/10.1016/j.geoderma.2008. 11.004

Camargo, O. A., Moniz, A. C., Jorge, J. A., \& Valadares, J. M. A. S. (1986). Métodos de análise química, mineralógica e física de solos do Instituto Agronômico de Campinas (Boletim Técnico, 106). Campinas: Instituto Agronômico.

Corá, J. E., Araujo, A. V., Pereira, G. T., \& Beraldo, J. M. G. (2004). Variabilidade espacial de atributos do solo para adoção do sistema de agricultura de precisão na cultura de cana-de-açúcar. Revista Brasileira de Ciência do Solo, 28, 1013-1021. https://doi.org/10.1590/S0100-06832004000600010

Cruz, A. C. R., Libardi, P. L., Carvalho, L. A., \& Rocha, G. C. (2005). Balanço de água no volume de solo explorado pelo sistema radicular de uma planta de citros. Revista Brasileira de Ciência do Solo, 29, 1-10. https://doi.org/10.1590/S0100-06832005000100001

EMBRAPA (Empresa Brasileira de Pesquisa Agropecuária). (2013). Sistema brasileiro de classificação de solos (3rd ed.). Rio de Janeiro: Embrapa Solos.

Fietz, C. R., Folegatti, M. V., Vieira, S. R., \& Frizzone, J. A. (1999). Efeito da variabilidade do armazenamento de água no solo na qualidade da irrigação por aspersão. Agriambi, 3, 150-153. https://doi.org/10.1590/ 1807-1929/agriambi.v3n2p150-153

Gao, L., Lv, Y., Wang, D., Tahir, M., \& Peng, X. (2015). Can shallow-layer measurements at a single location be used to predict deep soil water storage at the slope scale? J Hydrol, 3, 534-42. https://doi.org/ 10.1016/j.jhydrol.2015.11.002 
Gee, G. W. \& Or, D. (2002). Particle-size analysis. In J. H. Dane, \& G. C. Topp (Ed.), Methods of soil analysis: Physical methods (pp. 255-89). American Society of Agronomy.

Hu, W., Shao, M. A., Wang, Q. J., \& Reichardt, K. (2009). Time stability of soil water storage measured by neutron probe and the effects of calibration procedures in a small watershed. Catena, 79, 72-82. https://doi.org/10.1016/j.catena.2009.05.012

Kachanoski, R. G., \& de Jong, E. (1988). Scale dependence and the temporal persistence of spatial patterns of soil water storage. Water Resour Res., 24, 85-91.

Koorevaar, P., Menelik, G., \& Dirksen, C. (1999). Elements of soil physics. Amsterdam: Elsevier.

Libardi, P. L. (2012). Dinâmica da água no solo (2nd ed.). São Paulo: EDUSP.

Libardi, P. L., Manfron, P. A., Moraes, S. O., \& Tuon, R. L. (1996). Variabilidade da umidade gravimétrica de um solo hidromórfico. Revista Brasileira de Ciência do Solo, 20, 1-12.

Libardi, P. L., Mota, J. C. A., Assis Júnior, R. N., Brito, A. S., \& Amaro Filho, J. (2015). Water Balance Components in Covered and Uncovered Soil Growing Irrigated Muskmelon. Revista Brasileira de Ciência do Solo, 39, 1322-1334. https://doi.org/10.1590/01000683rbcs20140713

Melo Filho, J. F., \& Libardi, P. L. (2005). Estabilidade temporal de medidas do teor e do potencial mátrico da água no solo em uma transeção. Revista Brasileira de Ciência do Solo, 29, 497-506. https://doi.org/ $10.1590 / \mathrm{S} 0100-06832005000400002$

Mota, J. C. A., Libardi, P. L., Brito, A. S., Assis Júnior, R. N., \& Amaro Filho, J. (2010). Water storage and muskmelon productivity of a drip-irrigated soil with and without soil cover. Revista Brasileira de Ciência do Solo, 34, 1721-1731. https://doi.org/10.1590/s0100-06832010000500024

R Development Core Team. (2018). R Foundation for Statistical Computing. $R$ : A language and environment for statistical computing [internet]. Vienna: R Foundation for Statistical Computing. Retrieved May 20, 2018, from http://www.r-project.org

Ribeiro Júnior, P. J., \& Diggle, P. J. (2001). GeoR: A package for geostatistical analysis. R-News, 1, 15-8.

Rocha, G. C., Libardi, P. L., Carvalho, L. A., \& Cruz, A. C. R. (2005).Temporal stability of the spatial distribution of water storage in a soil under citrus cultivation. Revista Brasileira de Ciência do Solo, 29, 41-50. https://doi.org/10.1590/S0100-06832005000100005

Salvador, M. M. S., Libardi, P. L., Brito, A. S., \& Moreira, N. B. (2012). Estabilidade temporal e variabilidade espacial da distribuição da armazenagem de água no solo numa sucessão feijão/aveia-preta. Revista Brasileira de Ciência do Solo, 36, 1434-1447. https://doi.org/10.1590/S0100-06832012000500007

Schaffrath, V. R., Tormena, C. A., Fidalski, J., \& Gonçalves, A. C. A. (2008). Variabilidade e correlação espacial de propriedades físicas de solo sob plantio direto e preparo convencional. Revista Brasileira de Ciência do Solo, 32, 1369-1377. https://doi.org/10.1590/S0100-06832008000400001

Suzuki, L. E. A. S., Lima, C. L. R., Reinert, D. J., Reichert, J. M., \& Pillon, C. N. (2014). Estrutura e armazenamento de água em um Argissolo sob pastagem cultivada, floresta nativa e povoamento de eucalipto no Rio Grande do Sul. Revista Brasileira de Ciência do Solo, 38, 94-106. https://doi.org/ $10.1590 / \mathrm{S} 0100-06832014000100009$

Timm, L. C., Oliveira, J. C. M., Tominaga, T. T., Cássaro, F. A. M., Reichardt, K., \& Bacchi, O. O. S. (2002). Water balance of a sugarcane crop: Quantitative and qualitative aspects of its measurement. Agriambi, 6, 57-62. https://doi.org/10.1590/S1415-43662002000100011

Vachaud, G., Passerat, S. A., Balabanis, P., \& Vauclin, M. (1985). Temporal stability of spatially measured soil water probability density function. Soil Science Society of American Journal, 49, 822-827. https://doi.org/ 10.2136/sssaj1985.03615995004900040006x

Vieira, V. A. S., Mello, C. R., \& Lima, J. M. (2007). Variabilidade espacial de atributos físicos do solo em uma microbacia hidrográfica. Ciência e Agrotecnologia, 31, 1477-1485. https://doi.org/10.1590/S1413-70542 007000500031

Zanette, S. V., Silvestre, M. G., Boas, M. A. V., Uirbe-Opazo, M. A., \& Queiroz, M. M. F. (2007). Spatial analysis of soil moisture with soybean under two management systems. Agriambi, 11, 239-247. https://doi.org/10.1590/S1415-43662007000300001 


\section{Copyrights}

Copyright for this article is retained by the author(s), with first publication rights granted to the journal.

This is an open-access article distributed under the terms and conditions of the Creative Commons Attribution license (http://creativecommons.org/licenses/by/4.0/). 